\title{
The Psychometric Properties of Mindfulness Inventory in Sport and Examination of Its Measurement Invariance
}

\section{Las propiedades psicométricas del inventario de la atención plena en el deporte y el examen de su invariancia de medición}

\author{
Nazmi Baykose \\ Dr., Akdeniz University Faculty of Sport Sciences, Turkey \\ Buse Çelik \\ Res.Assist., Akdeniz University Faculty of Sport Sciences, Turkey
}

* Correspondence

Email: nazmibaykose@akdeniz.edu.tr
Citation:

Nazmi Baykose, Buse Çelik. (2021). The Psychometric Properties of Mindfulness Inventory in Sport and Examination of Its Measurement Invariance. Propósitos y Representaciones, 9 (SPE3) e11687. Doi: http://dx.doi.org/10.20511/pyr2021.v9nSPE3.1168 


\begin{abstract}
This study aimed to examine the psychometric properties and measurement invariance by testing the validity and reliability of the Turkish form of the "mindfulness inventory in sport, which was developed by Thienot et al. in 2014. Three different data sets were used in the study. Participants for the first data set consisted of 190 athletes ( mean $\left._{\text {age }}=21,37 \pm 2,74\right), 93$ women, and 97 men. The second data set consists of 258 athletes ( mean $\left._{\text {age }}=21,49 \pm 2,76\right), 128$ women and 130 men. Mindfulness Inventory in Sports is a 15-item measurement tool with three sub-dimensions (awareness, non-judgmental, refocusing), the first consists of 5 items, the second 5 items, and the third 5 items. Conscious Awareness Inventory in Sports has been developed to measure the conscious awareness levels of athletes. To examine the psychometric properties of the inventory, the first data set obtained with the participation of 190 athletes was used for reliability and EFA in the context of the construct validity study. The second data set obtained with the participation of 258 athletes was used in the CFA and multi-group confirmatory factor analysis process. The test-retest analysis was conducted with 40 athletes who were included in the research process independently from these two groups. Data analysis was done with SPSS and AMOS package programs. When the AFA results were examined, it was observed that there was no change in the original structure developed by Thienot et al. In the item analysis, it was concluded that all items were above. 30 , and the representation power of the inventory was sufficient. Besides, Cronbach's alpha internal consistency and test-retest methods were used to demonstrate the inventory's reliability. The study's findings showed that the Mindfulness Scale in Sports is valid and reliable in the Turkish athlete sample.
\end{abstract}

Keywords: Sport, mindfulness, validity, reliability

\title{
Resumen
}

Este estudio tuvo como objetivo examinar las propiedades psicométricas y la invariancia de medición probando la validez y confiabilidad de la forma turca del "inventario de atención plena en el deporte, que fue desarrollado por Thienot et al. En 2014. Se utilizaron tres conjuntos de datos diferentes en el Los participantes para el primer conjunto de datos consistieron en 190 atletas (edad media $=21,37 \square 2,74), 93$ mujeres y 97 hombres. El segundo conjunto de datos consta de 258 atletas (edad media $=21,49 \square 2,76), 128$ mujeres y 130 hombres. Mindfulness Inventory in Sports es una herramienta de medición de 15 ítems con tres subdimensiones (conciencia, no juzgar, reenfoque), la primera consta de 5 ítems, la segunda de 5 ítems y la tercera de 5 ítems. El Inventario de Conciencia Consciente en el Deporte ha sido desarrollado para medir los niveles de conciencia consciente de los atletas. Para examinar las propiedades psicométricas del inventario, se utilizó el primer conjunto de datos obtenido con la participación de 190 atletas para la confiabilidad y EFA en el contexto del constructo vali El segundo conjunto de datos obtenido con la participación de 258 atletas se utilizó en el proceso de análisis factorial confirmatorio CFA y multigrupo. El análisis test-retest se realizó con 40 atletas que fueron incluidos en el proceso de investigación independientemente de estos dos grupos. El análisis de datos se realizó con los paquetes de programas SPSS y AMOS. Cuando se examinaron los resultados de AFA, se observó que no hubo cambios en la estructura original desarrollada por Thienot et al. En el análisis de ítems, se concluyó que todos los ítems estaban por encima de .30, y el poder de representación del inventario fue suficiente. Además, se utilizó la consistencia interna alfa de Cronbach y los métodos test-retest para demostrar la confiabilidad del inventario. Los hallazgos del estudio mostraron que la Escala de Mindfulness en Deportes es válida y confiable en el atleta turco muestra.

Palabras clave: deporte, mindfulness, validez, fiabilidad.

\section{Introduction}

Nyanaponika (1972) Thera defines consciousness as "the state of our perceptions focusing on what is happening in us and our in-worldly in successive moments and being clear". Although it is a psychological approach that emphasizes the importance of the present moment based on Buddhism 
and Eastern meditation based on mindfulness practice, it also appears as an attention directing technique related to being in contact with our daily life by being accepted in western culture (Kabat Zinn, 2009; Balci, 2018; Ozyesil, 2011). Mindfulness, an old tradition, has started to attract a lot of attention in recent years and has begun to be applied in these areas as the subject of psychologists, neuroscientists, and clinicians (Siegel et al., 2009). Mindfulness examines one's thoughts, feelings, and physical body, "What am I living now?" is his/her answer to the question. In this respect, mindfulness means focusing on the changes that a person is currently feeling, thinking, perceiving with his/her sensory organs, and noticing in his body (Demir, 2014).

Bishop et al. proposed a two-component model of mindfulness. The first component refers to the self-regulation of attention, which includes monitoring current thoughts, emotions, and feelings, moving from one focus of attention to another, and preventing elaborate processes such as anxiety and rumination. The second component involves adopting a state of acceptance for every moment of his experience, which can be defined by a non-judgmental attitude of openness and curiosity that allows any thoughts, feelings, and feelings to occur without further elaboration (Bishop et al., 2004).

As a unique attention strategy, mindfulness has become the subject of sport. The performance-oriented nature of sport requires a constant focus on goal-related cues while distinguishing harmful stimuli (Gardner; Moore, 2007; Moran, 2009). Gardner and Moore identified three components in their model: (1) awareness of current thoughts, feelings, and bodily feelings; (2) acknowledgment representing a non-judgmental attitude towards one's current beliefs, emotions, and physical senses; and (3) adherence to goal-related actions, which can be defined by maintaining a goal-directed focus of attention and behavior (Gardner; Moore, 2007).

Mindfulness-based programs aimed at increasing sports performance have been developed (Bernier Et Al., 2009; Gardner; Moore, 2004). However, to date, these programs have not been supported by a subject-specific tool to assess conscious awareness skills among those who do sports properly. Mindfulness tools designed for use in clinical settings consist of items developed for the daily life situation and, therefore, not specific to sports (Baer; Smith; Allen, 2004; Brown; Ryan, 2003; Cardaciotto et al., 2008). Determining the state of mindfulness can help determine when a person is directing their focus on distractions, acknowledging these factors' presence, and refocusing the person's attention effectively on goal-related cues (GARDNER; MOORE, 2007). Due to contextual differences in clinical and sports settings, the importance of developing a context-specific tool for measuring mindfulness processes in sports is emphasized. By a model proposed in sport, such a tool includes an awareness component (i.e., the awareness of destructive thoughts, feelings, and bodily sensations that arise in the stream of consciousness), the attitudinal component of acceptance (i.e., accepting the presence of damaging stimuli without self-judgment to experience them) and a refocusing component (i.e., transforming the focus of attention from destructive incentives to useful goal-directed cues) (GARDNER; MOORE, 2007).

\section{Literature Review}

Increases in performance-related variables such as mindfulness, athletic coping (JOSEFSSON et al., 2017), flow (KAUFMAN et al., 2009) have also been associated with a decrease in competition anxiety (ROTHLIN et al., 2016). Overall, these results suggest that the application of mindfulness skills in sports competitions may be related to athletic performance improvement. In this context, measuring Mindfulness is extremely important. However, there was no inventory to measure the Mindfulness levels of Turkish athletes until the current year. Preliminary findings of the Turkish form of the Mindfulness Inventory in Sports were published by Tingaz (2020). However, some psychometric properties were not studied. In this context, it aimed to examine the psychometric properties of the mindfulness inventory for sport by conducting some additional analyses. 


\section{Method}

\section{Participants}

Three different data sets were used in the study. Participants in the first data set consist of 190 athletes (mean age: $21.37 \pm 2.74), 93$ women and 97 men. The second data set consists of a total of 258 (mean $n_{\text {age: }} 21.49 \pm 2.76$ ) athletes (team and individual sports), 128 women, and 130 men. The test-retest analysis was carried out with a separate group of participants consisting of 40 athletes from different sports branches (football, archery, volleyball, handball, and wrestling), who were included in the research process independently from these two groups. All participants were informed about the study's purpose and were included in the study after their consent.

\section{Materials}

For the research, Mindfulness Inventory in Sports, Multidimensional Perfectionism Scale in Sport, Ruminative Response Scale-Short Form, and Personal Information Form were used.

\section{Mindfulness Inventory for Sport (MIS)}

Mindfulness Inventory in Sports is a 15-item measurement tool developed by Thienot et al., with three sub-dimensions, the first of which consists of 5 items, the second of 5 items, and the third of 5 items (THIENOT et al., 2014). Mindfulness Inventory in Sports has been developed to measure the mindfulness levels of athletes. Mindfulness Inventory in Sports was designed using a three-step approach to measure one's mindfulness-related abilities, as stated by Thienot et al. (2014). First, it measures awareness of harmful stimuli and their associated internal reactions; secondly, adopting a non-judgmental attitude towards these stimuli and responses, and thirdly refocusing attention rapidly on goal-directed cues.

\section{Multidimensional Perfectionism Scale in Sport (MPSS)}

The scale of perfectionism in sports (BMI) was developed by Dunn et al. as four sub-dimensions (personal standards, dealing with errors, perceived family pressure, and perceived coach pressure) and 30 items to measure the perfectionism level of athletes (DUNN; DUNN; SYROTUIK, 2002). The adaptation study of the scale for Turkish athletes' sample was carried out by Çepikkurt [21]. As a result of the analysis of scale items by Çepikkurt, a structure consisting of 19 items and three subfactors emerged (CEPIKKURT, 2011). It was reported that the "perceived coach pressure" subscale in the original scale did not work in the Turkish athlete population. When the Cronbach's alpha internal consistency values were examined, it was seen that it was . 76 for the excessive concern with errors subscale, .76 for the personal standards subscale, and .77 for the perceived family pressure subscale.

\section{Ruminative Response Scale-Short Form (RRS-SF)}

The Ruminative Response Scale is a scale based on Nolen-Hoeksema and Morrow's 22-item scale, focusing on the use of individuals' rumination as a coping mechanism (NOLEN-HOEKSEMA; MORROW, 1991). Due to the overlap between the items of the original scale and the items of the depression scales, Treynor et al. (2003) removed the items related to depression. They had a 10-item scale measuring two dimensions of rumination: obsessive thinking (5 items) and reflective thinking (5 items) (TREYNOR et al., 2003). Each item is rated as 4 Likert types. The original scale's psychometric properties show sufficient reliability (total RSQ-SF score for preoccupied thinking and reflection, respectively $.85, .72$, and .77). The scale was translated into Turkish by Baker and Bugay (2012). The Turkish version appears to have satisfactory validity levels with Cronbach's alphas of $.85, .77$, and .75 (for the total score, reflection, and obsessive thinking). 


\section{Personal Information Form}

Age, gender, sports experience, and branch variables were included in the researchers' information form.

\section{Procedure}

\section{Authorization Procedure}

Emilie Thienot was contacted by the first author by e-mail on Sunday, April 29, 2018, at 16:46, and she was asked that we would like to carry out the adaptation of the scale to the Turkish sample whether someone else had contacted her previously for the Turkish population. On May 5, 2018, at 00:59 that there is no problem that we can carry out the adaptation of the scale and that we can contact her when we need his assistance in the process.

\section{Translation Procedure}

To carry out the validity and reliability study of the Mindfulness Inventory in Sports, first of all, the ways of translating the scale into the target language, returning the translated scale to the target language to the original language, and seeking expert opinion were followed. The scale, whose original language is English, was translated into Turkish by two linguists and two experts from sports psychology. During the translation, the experts did their translations individually without communicating with each other. After the translations were done separately, experts came together to compare the translations and decide on the optimal translation. Back translation was done by two different linguists who did not know the original scale. The back-translated adaptation scale and the original scale were compared by taking expert opinions, and the Turkish Scale was finalized. No new expression was developed in its translation into Turkish, and the original form of the scale has fully adhered.

\section{Data Analysis}

During the data analysis process, two separate data sets were used. The first data set obtained with the participation of 190 athletes was used for reliability and EFA. The second data set obtained with the participation of 258 athletes was used in the CFA and multi-group confirmatory factor analysis process. The test-retest analysis was carried out with a separate group of participants consisting of 40 athletes from different sports branches (football, archery, volleyball, handball, and wrestling), who were included in the research process independently from these two groups. Two different analysis programs were used in the data analysis process. The first of these is SPSS 25 and the second is the AMOS package program. Before starting the analysis process, the data set was checked, and no incorrect or missing data were detected. Exploratory factor analysis and confirmatory factor analysis were used in the construct validity study to examine the Mindfulness Inventory in Sports' psychometric properties. Since exploratory factor analysis is used to explore the factor structure of a measurement tool in a particular study group or sample, it is questioned whether the obtained factor structure and results can be obtained in similar data sets and different samples; in other words, its reproducibility (COKLUK et al., 2018). Confirmatory factor analysis, on the other hand, was used to test whether a previously determined theoretical structure was structurally verified (COKLUK et al., 2018). In the confirmatory factor analysis, Chi-Square Goodness Test (Chi-Square Goodness), Comparative Fit Index (CFI), Standardized Root Mean Squared Residuals (SRMR), and Root Mean Square Error of Approximation (RMSEA) were used to determine the tested model. It is stated that the acceptable fit value for RMSEA and SRMR values is .08 (BROWN; CUDECK, 1993), the acceptable fit value for the CFI index is 90 (BENTLER, 1980; BENTLER; BONET, 1980; SCHERMELLEH-ENGEL et al., 2003), and the $\mathrm{x}^{2} / \mathrm{sd}$ acceptable value is less than 3 (SCHERMELLEH-ENGEL et al., 2003). Internal consistency coefficients and test-retest correlation coefficients were calculated for the reliability of the scale. Item analysis was analyzed with the corrected item-total score correlation. 


\section{Results}

The Findings Related to Construct Validity of Mindfulness Inventory for Sport

Table 1. EFA Findings for MIS

\begin{tabular}{|c|c|c|c|}
\hline & \multicolumn{3}{|c|}{ Components } \\
\hline & 1 & 2 & 3 \\
\hline Item 12 &, 823 & & \\
\hline Item 14 &, 816 & & \\
\hline Item 11 &, 799 & & \\
\hline Item 13 &, 611 & & \\
\hline Item 15 &, 589 & & \\
\hline Item 1 & &, 748 & \\
\hline Item 3 & &, 735 & \\
\hline Item 2 & &, 726 & \\
\hline Item 4 & &, 720 & \\
\hline Item 5 & & 631 & \\
\hline Item 9 & & &, 815 \\
\hline Item 8 & & &, 748 \\
\hline Item 10 & & & ,690 \\
\hline Item 7 & & & ,687 \\
\hline Item 6 & & & ,630 \\
\hline Eigenvalue & 5,008 & 2,244 & 1,429 \\
\hline Variance $(\%)$ & 33,388 & 14,962 & 9,527 \\
\hline
\end{tabular}

First, AFA was carried out using Varimax rotation. Before the analysis, Kaiser-Meyer Olkin (KMO) and Bartlett's tests were applied to determine whether the data were suitable for factor analysis. As expected, the KMO value was found to be 84 , over 50, and the result of Bartlett's test was significant, $\chi^{2}(105, \mathrm{~N}=190)=1030,231 ; \mathrm{p}<0.001$. These results show that the relationships between items are suitable for factor analysis. According to the EFA results, it was observed that three factors with an eigenvalue greater than 1 explained $56.93 \%$ of the total variance. After the rotation, the first factor consists of $5(11,12,13,14,15)$, the second factor consists of $5(1,2,3,4$, $5)$, and the third factor consists of $5(6,7,8,9,10)$ items, and factor loads were found to vary between,59 and,82 (see Table 1). 
Table 2. CFA Findings for MIS

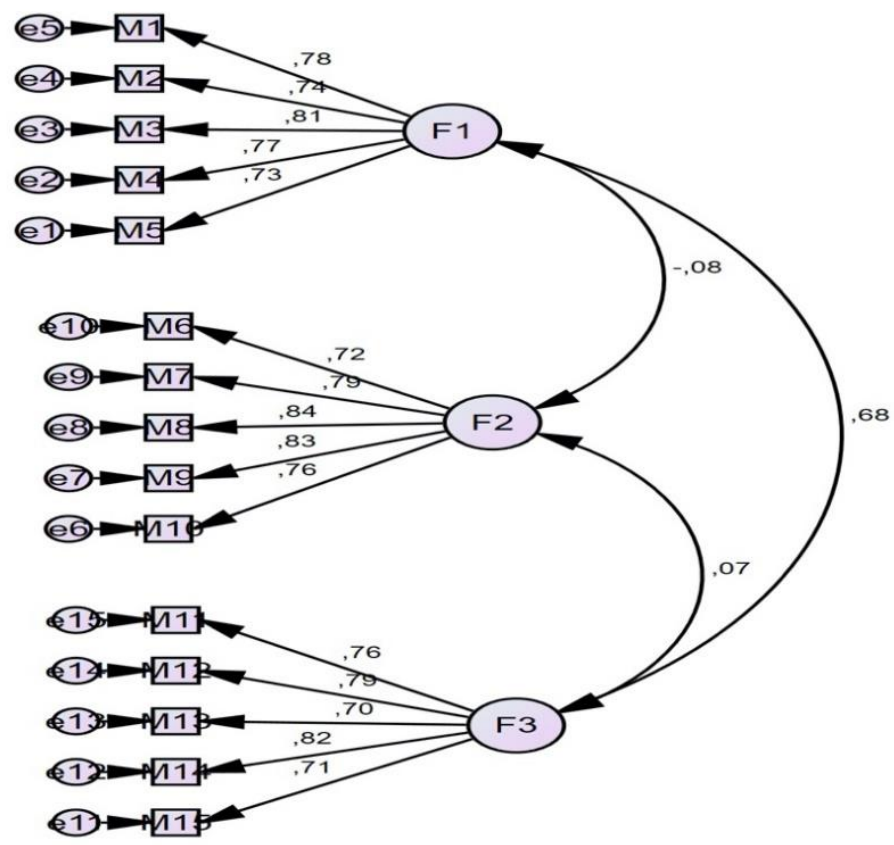

Factors and Standardized Factor Loadings for MIS

$\chi^{2}(86)=228.459, \mathrm{p}<.001, \chi 2 / \mathrm{sd}=2.65, \mathrm{CFI}=.96, \mathrm{TLI}=.95, \mathrm{AIC}=301.412, \mathrm{BIC}=$ $459.943, \mathrm{ECVI}=.94, \mathrm{RMSEA}=.07 \mathrm{CI}[.04, .06]$.

Table 3. Criterion-related Validity Findings

\begin{tabular}{|c|c|c|c|c|c|c|c|c|}
\hline & Mean & S.D & Skewness & Kurtosis & 1 & 2 & 3 & 4 \\
\hline 1.Awareness & 4,2916 &, 63298 & $-1,751$ & 1,282 & - & & & \\
\hline 2.Non-judgmental & 2,4368 &, 93927 &, 857 &, 585 &,$- 431^{* *}$ & - & & \\
\hline 3.Refocusing & 3,9474 &, 79773 & $-1,109$ & 1,689 &, $502^{* *}$ &, $286^{* *}$ & - & \\
\hline 4.RR & 3,8719 &, 62167 &,- 171 &,- 626 &,- 031 &,- 103 &, 035 & - \\
\hline 5.MPSS & 3,2047 &, 77499 &, 124 &, 310 &, $153^{*}$ &,$- 146^{*}$ &, 103 &, $190^{* *}$ \\
\hline
\end{tabular}

Note. **p <.001; *p <.01. Awareness (1), Non-judgmental (2), Refocusing (3), RR (4), MPSS (5) MPSS: Multidimensional Perfectionism Scale in Sport

RR: Rumination Reconsidered

When Table 3 is examined, it is seen that all sub-dimensions of the mindfulness inventory in sports are correlated with each other. At the same time, there is a negative relationship between the sub-dimensions of uncritical attitude and perfectionism.

\section{Reliability Analysis Findings}

Table 4. Internal Consistency Coefficient and Test-Retest Reliability Analysis Findings

\begin{tabular}{ccccc}
\hline & 1 & 2 & 3 & Total \\
\hline $\begin{array}{c}\text { Internal consistency } \\
\text { coefficient (Alpha) }\end{array}$ & .84 & .88 & .77 & .86 \\
\hline $\begin{array}{c}\text { Test-retest correlation } \\
\text { coefficient * }\end{array}$ & .89 & .90 & .88 & .89 \\
\hline
\end{tabular}

\section{*subdimensions 1:}

When Table 4 is examined, it is seen that the internal consistency coefficient of all subdimensions has values above .70. Also, test-retest correlations are above .80 .

\section{Item Analysis Findings}


Table 5. Analysis of Each Item Regarding Awareness Sub-Dimension of Mindfulness Inventory in Sports

\begin{tabular}{ccccc}
\hline Items & $\begin{array}{c}\text { Arithmetic Average } \\
\text { if item deleted }\end{array}$ & $\begin{array}{c}\text { Variance if item } \\
\text { deleted }\end{array}$ & $\begin{array}{c}\text { Item Sub- } \\
\text { Dimension Total } \\
\text { Correlation }\end{array}$ & $\begin{array}{c}\text { Cronbach Alpha if } \\
\text { item deleted }\end{array}$ \\
\hline 1 & 17,07 & 6,70 &, 59 &, 75 \\
2 & 17,02 & 7,30 &, 53 &, 77 \\
3 & 17,04 & 6,75 &, 62 &, 74 \\
4 & 17,22 & 6,46 &, 59 &, 75 \\
5 & 17,48 & 6,51 &, 55 &, 77 \\
\hline
\end{tabular}

The Cronbach's alpha internal consistency coefficient of the awareness sub-dimension was found to be 0.84 . When the Cronbach alpha coefficient values are obtained if each item is deleted, it is seen that the reliability coefficient decreases. The sub-dimension total correlation coefficients of the awareness sub-dimension items were found as the highest .62 (item 3) and the lowest .53 (item 2). The item prediction power of the items in the non-critical sub-dimension, the Cronbach alpha reliability coefficient of the sub-dimension if an item is deleted, and the multiple correlation values are given in Table 6 for all participants.

Table 6. Analysis of Each Item Regarding the Non-Judgmental Sub-Dimension of the Mindfulness Inventory in Sports

\begin{tabular}{ccccc}
\hline Items & $\begin{array}{c}\text { Arithmetic } \\
\text { Average if item } \\
\text { deleted }\end{array}$ & $\begin{array}{c}\text { Variance if item } \\
\text { deleted }\end{array}$ & $\begin{array}{c}\text { Item Sub- } \\
\text { Dimension Total } \\
\text { Correlation }\end{array}$ & $\begin{array}{c}\text { Cronbach Alpha if item } \\
\text { deleted }\end{array}$ \\
\hline 6 & 14,54 & 12,25 &, 50 &, 74 \\
7 & 14,70 & 11,61 &, 56 &, 72 \\
8 & 14,81 & 12,050 &, 56 &, 72 \\
9 & 14,99 & 11,55 &, 60 &, 70 \\
10 & 14,95 & 11,98 &, 47 &, 75 \\
\hline
\end{tabular}

The Cronbach alpha internal consistency coefficient of the non-judgmental sub-dimension was found to be 0.88 . When the Cronbach alpha coefficient values are obtained if each item is deleted, it is seen that the reliability coefficient decreases. The sub-dimension total correlation coefficients of the awareness sub-dimension items were found as the highest .60 (item 9) and the lowest 47 (item 10). The item prediction power of the items in the refocusing sub-dimension, the Cronbach alpha reliability coefficient of the sub-dimension when the item is deleted, and the multiple correlation values are given in Table 7 for all participants.

Table 7. Analysis of Each Item Regarding Refocusing Sub-Dimension of Mindfulness Inventory in Sports

\begin{tabular}{ccccc}
\hline Items & $\begin{array}{c}\text { Arithmetic Average } \\
\text { if item deleted }\end{array}$ & $\begin{array}{c}\text { Variance if } \\
\text { item deleted }\end{array}$ & $\begin{array}{c}\text { Item Sub- } \\
\text { Dimension Total } \\
\text { Correlation }\end{array}$ & $\begin{array}{c}\text { Cronbach Alpha if item } \\
\text { deleted }\end{array}$ \\
\hline 11 & 15,85 & 10,49 &, 63 &, 80 \\
12 & 15,84 & 10,22 &, 66 &, 79 \\
13 & 15,67 & 11,51 &, 56 &, 82
\end{tabular}


The internal consistency coefficient of the refocus sub-dimension is 0.77 . When the Cronbach alpha coefficient values are obtained if each item is deleted, it is seen that the reliability coefficient remains the same when the 14th item is deleted, and the reliability coefficient increases when the other items are deleted. The sub-dimension total correlation coefficients of the subdimension items were the highest at 0.72 (item 14) and the lowest at 0.56 (item 13).

Table 8. Item Fit Index Findings Regarding the Whole Mindfulness Inventory in Sports

\begin{tabular}{ccccc}
\hline Items & $\begin{array}{c}\text { Arithmetic Average } \\
\text { if item deleted }\end{array}$ & $\begin{array}{c}\text { Variance if item } \\
\text { deleted }\end{array}$ & $\begin{array}{c}\text { Item Sub- } \\
\text { Dimension Total } \\
\text { Correlation }\end{array}$ & $\begin{array}{c}\text { Cronbach Alpha if item } \\
\text { deleted }\end{array}$ \\
\hline 1 & 55,33 & 69,56 &, 52 &, 84 \\
2 & 55,28 & 71,35 &, 46 &, 85 \\
3 & 55,30 & 69,89 &, 53 &, 84 \\
4 & 55,48 & 68,90 &, 53 &, 84 \\
5 & 55,74 & 68,20 &, 55 &, 84 \\
6 & 55,76 & 68,74 &, 40 &, 85 \\
7 & 55,93 & 65,08 &, 59 &, 84 \\
8 & 56,03 & 68,47 &, 44 &, 85 \\
9 & 56,21 & 68,99 &, 39 &, 85 \\
10 & 56,17 & 67,58 &, 42 &, 85 \\
11 & 55,83 & 68,79 &, 44 &, 84 \\
12 & 55,82 & 67,95 &, 49 &, 54 \\
13 & 55,65 & 68,99 & 67,03 &, 50 \\
15 & 55,80 & 66,82 &, 50 &, 85 \\
\hline
\end{tabular}

As a result of the item consistency analysis of the Mindfulness Inventory in Sports, the Cronbach $\alpha$ value was found to be 0.86 . When the Cronbach alpha coefficient values obtained if each item is deleted, it is seen that the reliability coefficient decreases if the items are deleted.

Table 9. Multiple Group Confirmatory Factor Analysis for MIS

\begin{tabular}{|c|c|c|c|c|c|c|c|c|c|c|c|}
\hline Model & df & CMIN & $\mathrm{X}^{2}$ & $\begin{array}{c}\text { CF } \\
\text { I }\end{array}$ & $\begin{array}{c}\text { SRM } \\
\text { R }\end{array}$ & $\begin{array}{c}\text { RMSE } \\
\text { A }\end{array}$ & $\Delta \mathrm{x}^{2}$ & $\begin{array}{c}\Delta s \\
\mathrm{~d}\end{array}$ & $\begin{array}{c}\mathrm{P}(\Delta \mathrm{x} \\
2\end{array}$ & $\begin{array}{c}\Delta \mathrm{CF} \\
\mathrm{I}\end{array}$ & $\begin{array}{c}\Delta \mathrm{RMS} \\
\mathrm{A}\end{array}$ \\
\hline Gender \\
\hline $\begin{array}{c}\text { Baseline } \\
\text { males }\end{array}$ & 86 & $\begin{array}{c}127,46 \\
9\end{array}$ & 1,482 & $\begin{array}{c}95 \\
6\end{array}$ & 064 &, 061 & - & - & - & - & - \\
\hline
\end{tabular}




\begin{tabular}{|c|c|c|c|c|c|c|c|c|c|c|c|}
\hline $\begin{array}{l}\text { Baseline } \\
\text { females }\end{array}$ & 35 & 234 , & 2,761 & $\begin{array}{c}94 \\
7\end{array}$ & 073 & 079 & - & - & - & - & - \\
\hline $\begin{array}{l}\text { Configural } \\
\text { invariance }\end{array}$ & $\begin{array}{c}17 \\
2\end{array}$ & $\begin{array}{c}359,70 \\
3\end{array}$ & $\begin{array}{c}2,091 \\
*\end{array}$ & $\begin{array}{c}91 \\
6\end{array}$ & ,064 & ,068 & - & - & - & - & - \\
\hline $\begin{array}{c}\text { Metric } \\
\text { invariance }\end{array}$ & $\begin{array}{c}18 \\
4\end{array}$ & $\begin{array}{c}385,50 \\
2\end{array}$ & $\begin{array}{c}2,095 \\
*\end{array}$ & $\begin{array}{c}, 91 \\
6\end{array}$ & ,063 & ,065 & $\begin{array}{c}00 \\
4\end{array}$ & &, $000 *$ & $\begin{array}{c}0,00 \\
0\end{array}$ & ,003 \\
\hline $\begin{array}{c}\text { Scalar } \\
\text { invariance }\end{array}$ & $\begin{array}{c}19 \\
0\end{array}$ & $\begin{array}{c}397,66 \\
8 \\
\end{array}$ & 2,093 & $\begin{array}{c}, 91 \\
4\end{array}$ & 071 & ,064 & $\begin{array}{c}, 00 \\
2 \\
\end{array}$ & &, $000^{*}$ & $\begin{array}{c}0,00 \\
2\end{array}$ & ,008 \\
\hline $\begin{array}{l}\text { Stric/Resid } \\
\text { ual } \\
\text { Invariance }\end{array}$ & $\begin{array}{c}20 \\
6\end{array}$ & $\begin{array}{c}442,20 \\
6\end{array}$ & 2,146 & $\begin{array}{c}, 89 \\
7\end{array}$ & 073 & ,068 & $\begin{array}{c}, 05 \\
3\end{array}$ & &, $000 *$ & $\begin{array}{c}0,00 \\
7\end{array}$ & ,004 \\
\hline
\end{tabular}

$* \mathbf{p}<\mathbf{0 , 0 0 1}$

In the study, multiple group confirmatory factor analyzes were conducted to examine whether the mindfulness inventory in sports has a measurement invariance according to gender. In the study, the configural invariance, metric invariance, and Strict/residual invariance of the sport's mindfulness inventory were examined. It has been observed that the configural model, in which the parameters are freely estimated, and the metric model in which the factor loads equality between groups are provided, fit well with the data set. The goodness of fit values for the structural model were $\chi 2(172)=359.703, \mathrm{p}>.05, \chi^{2} / \mathrm{df}=2.091, \mathrm{CFI}=.916$, RMSEA $=.068$ CI $[.04, .06]$, while the goodness of fit values of the metric model were $\chi 2(184)=385.502, \mathrm{p}>.05,2 / \mathrm{sd}=2.095, \mathrm{CFI}$ $=.92, \mathrm{RMSEA}=.065 \mathrm{CI}[.04, .06]$. A good fit of the configural model to the data set showed that the measurement tool has configural invariance according to gender. Metric invariance was tested by comparing the configrual and metric model based on $\triangle \mathrm{CFI}<.01$ and $\triangle \mathrm{RMSEA}<.015$ criteria. The $\triangle \mathrm{CFI}=.000$ and $\triangle \mathrm{RMSEA}=.003$ values obtained in the analyzes showed that the mindfulness inventory in sports has metric invariance according to the gender variable (female, male). Likewise, when the process is performed by comparing the metric and scalar models, the values obtained for scalar invariance according to the gender variable (female, male) in the analyzes show that the inventory has scalar invariance. Finally, when scalar and residual models are compared according to the gender variable (female, male) in the analyzes, the CFI values $=.002$ and $\triangle \mathrm{RMSEA}=.008$ obtained for residual invariance show that the inventory has residual invariance.

\section{Discussion and Conclusion}

This research aimed to examine the psychometric properties and measurement invariance of the mindfulness inventory in sports within the scope of this research. When the AFA results performed in this direction were examined, it was seen that there was no change in the original structure developed by Thienot et al. (2014).

Within this research's scope, the item prediction power of the items in each sub-dimension of the scale, the Cronbach alpha reliability coefficient, and multiple correlation values of the subdimension when the item was deleted were examined. First, item analysis was conducted, and it was examined whether the scale items had sufficient representation power. In evaluating item-total correlations, it is accepted that the scale of items with values of .30 and above is adequate (Buyukozturk, 2004). The item analysis concluded that all items were above .30, and the representation power of the scale was sufficient.

Also, Cronbach alpha internal consistency and test-retest methods were used to demonstrate the reliability of the Mindfulness Inventory in Sports. The Cronbach alpha internal consistency coefficient calculated with the data obtained from 190 people was found to be .86 . Cronbach alpha internal consistency coefficient was calculated for each sub-dimension of the scale. It was determined that the reliability coefficient decreased when items were deleted in both awareness and non-judgmental sub-dimensions. In refocusing the sub-dimension, it is seen that the reliability coefficient increases when items except item 14 are deleted. However, when the total item fit index findings of the scale were examined, the Cronbach $\alpha$ value was 0.86 . The reliability coefficient decreased when the items were deleted. These results show that the reliability of the inventory is at an acceptable level. 
In this study on the Turkish adaptation of the mindfulness inventory in sports, it is seen that there is an interesting link between awareness and perfectionism in sports, as stated by Thienot et al. (2014). First, the positive correlation between the MIS awareness subscale and MPSS may reflect the tendency of perfectionists to focus on themselves and pay attention to their thoughts and feelings, as reported by Thienot et al. (2014) (Frost et al., 1990; Saboonchi; Lundh, 1997).

In the study, multiple group confirmatory factor analyzes were conducted to examine whether the mindfulness inventory in sports has a measurement invariance according to gender. In this study, the configural invariance, metric invariance, and strict/residual invariance of the mindfulness inventory in sports were examined by gender. Brown's recommended guideline on measurement invariance was followed (Brown, 2014). As a result of the research, measurement equivalence analysis showed that there is measurement equivalence in groups by gender (Brown, 2014; Chen, 2007). The study's findings showed that the mindfulness inventory for sports is valid and reliable in the Turkish athlete sample. In future research, calculating the intercultural invariance of the scale will provide additional information on the inventory's international use.

\section{References}

BAER, R. A.; SMITH, G. T.; ALLEN, K. B. Assessment of mindfulness by selfreport: the Kentucky inventory of mindfulness skills. Assessment, 2004; 11: 191-206. http://dx.doi.org/10.1177/1073191104268029.

BAKER, O.E.; BUGAY, A. The Turkish version of the Ruminative Response Scale: An examination of its reliability and validity. The International Journal of Educational and Psychological Assessment, 2012; 10(2):1-16.

BALCI, Y. Evaluation of emotional intelligence and psychological resilience in a sample of six-week modified mindfulness practice (Unpublished Master's Thesis), Beykent University, İstanbul, 2018.

BENTLER, P. M. Multivariate analysis with latent variables: Causal modeling. Annual Review of Psychology, 1980; 31: 419-456.

BENTLER, P. M.; BONET, D. G. Signifcance tests and goodness of fit in the analysis of covariance structures. Psychological Bulletin, 1980; 88: 588-606.

BERNIER, M. et al. A multi-study investigation examining the relationship between mindfulness and acceptance approaches and sport performance. Journal of Clinical Sport Psychology, 2009; 3, 320333. http://dx.doi.org/10.1037/a0030220.

BISHOP, S.R. et al. Mindfulness: A proposed operational definition. Clinical Psychology: Science and Practice, 2004; 11:230-241. doi:10.1093/clipsy.bph077

BROWN, K. W.; RYAN, R. M. The benefits of being present: mindfulness and its role in psychological wellbeing. Journal of Personality and Social Psychology, 2003, 84: 822-848. http://dx.doi.org/10.1037/0022-3514.84.4.822.

BROWN, M.; CUDECK, R. Alternative ways of assessing model fit. In: K. A. Bollen ve J. S. Long (Eds.), Testing structural equation models. Beverly Hills, CA: Sage. 1993; 136-162.

BROWN, T. A. Confirmatory factor analysis for applied research. Guilford Publications, 2014.

BUYUKOZTURK, S. Data Analysis Handbook. Ankara: Pegem A Publishing, 2004.

CARDACIOTTO, L. et al. The assessment of present-moment awareness and acceptance: the Philadelphia mindfulness scale. Assessment, 2008; 20: 2-21. http://dx.doi.org/10.1177/ 1073191107311467.

CEPIKKURT, F. Examination of the relationship between the perfectionism and anxiety levels of university handball players with their achievement goals and the way they attribute the results of the competition. (Unpublished Doctoral Thesis). Çukurova University Institute of Health Sciences, Adana, 2011.

CHEN, F. F. Sensitivity of goodness of fit indexes to lack of measurement invariance. Structural equation modeling: a multidisciplinary journal, 2007;14(3): 464-504.

COKLUK, O. et al. Multivariate statistics for social sciences: SPSS and LISREL applications (Vol. 5). Pegem Academi, Ankara, 2018.

DEMIR, V. The effect of the conscious awareness-based training program on individuals' depression and stress levels (Unpublished Master's Thesis), İstanbul Arel University, İstanbul, 2014.

DUNN, J. G.; DUNN, J. C.; SYROTUIK, D. G. Relationship between multidimensional perfectionism and goal orientations in sport. Journal of Sport and Exercise Psychology, 2002; 24(4): 376-395.

FROST, R. O. et al. The dimensions of perfectionism. Cognitive Therapy and Research, 1990; 14: 449-468.

GARDNER, F. L.; MOORE, Z. E. A Mindfulness-Acceptance-Commitment (MAC) based approach to athletic performance enhancement: theoretical considerations. Behavior Therapy, 2004; 35: 707-723.

GARDNER, F. L.; MOORE, Z. E. The psychology of enhancing human performance: The MindfulnessAcceptance-Commitment (MAC) approach. New York: Springer, 2007. 
JOSEFSSON, T. et al. Mindfulness mechanisms in sports: Mediating effects of rumination and emotion regulation on sport-specific coping. Mindfulness, 2017; 8(5): 1354-1363.

KABAT ZINN, J. Be there wherever you are. Kuraldısı publishing, İstanbul, 2009.

KAUFMAN, K.A. et al. Evaluation of mindful sport performance enhancement (MSPE): A new approach to promote flow in athletes. Journal of Clinical Sport Psychology, 2009; 3(4), 334-356.

MORAN, A. P. Cognitive psychology in sport: progress and prospects. Psychology of Sport and Exercise, 2009; 10(4): 420-426.

NOLEN-HOEKSEMA, S.; MORROW, J. A prospective study of depression and posttraumatic stress symptoms after a natural disaster: the 1989 Loma Prieta Earthquake. Journal of personality and social psychology, 1991; 61(1): 115.

NYANAPONIKA, T. The Power of Mindfulness. San Francisco, CA: Unity Press, 1972.

OZYESIL, Z. Investigation of the self-understanding levels of university students in terms of conscious awareness personality traits and some variables (Unpublished Master's Thesis), Selcuk University, Konya, 2011.

ROTHLIN, P. et al. Mindfulness promotes the ability to deliver performance in highly demanding situations. Mindfulness, 2016; 7: 727-733.

SABOONCHI, F.; LUNDH, L.-G. Perfectionism, self-consciousness and anxiety.Personality and Individual Differences, 1997; 22: 921-928.

SCHERMELLEH-ENGEL, K. et al. Evaluating the fit of structural equation models: Tests of significance and descriptive goodness-of-fit measures. Methods of psychological research online, 2003; 8(2): 23-74.

SIEGEL, R. D. et al. Mindfulness: What Is It? Where Does It Come From? Clinical Handbook of Mindfulness, New York: Springer. 2009; 17-35.

THIENOT, E. et al. Development and preliminary validation of the mindfulness inventory for sport. Psychology of Sport and Exercise, 2014; 15(1): 72-80

TINGAZ, E. O. Adaptation of the mindfulness inventory for sport into turkish: a validity and reliability study. Spormetre Journal of Physical Education and Sport Sciences, 2020; 18(1): 71-80.

TREYNOR, W. et al. Rumination reconsidered: A psychometric analysis. Cognitive therapy and research, 2003; 27(3): 247-259. 